\begin{tabular}{l} 
2. To: (Receiving Organizat \\
WRAP 1 \\
\hline 5. Proj./Prog./Dept./Div.: \\
W026/Sol id Waste \\
Construction \\
\hline
\end{tabular}

8. Originator Remarks:

For release

11. Receiver Rentarks:

\author{
3. From: (Originating Organization) \\ WRAP 1 \\ 6. Design Authority/ Design Agent/Cog. \\ Engr.: \\ TL Watson
}
4. Retated EDT No.:
$\mathrm{N} / \mathrm{A}$
7. Purchase Order No.:
$\mathrm{N} / \mathrm{A}$

11A. Design Baseline Document? [] Yes [X] No

9. Equip./Component No.:

$N / A$

10. System/Bldg./Facility:

$\mathrm{N} / \mathrm{A}$

12. Major Assm. Dwg. No.:

$N / A$

13. Permit/Permit Application No.: N/A

14. Required Response Date:

N/A

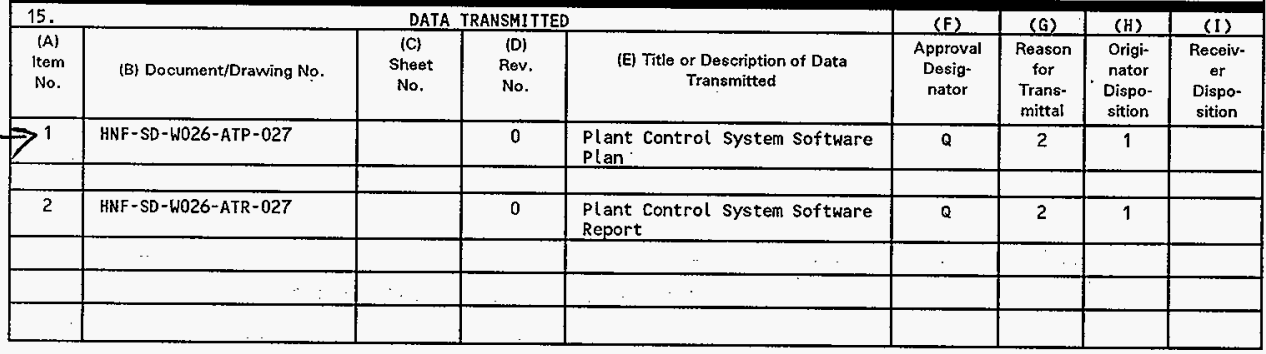

\begin{tabular}{|l|ll|ll|}
\hline 16. & \multicolumn{3}{|c|}{ KEY } \\
\hline \multicolumn{1}{|c|}{ Approval Designator (F) } & \multicolumn{1}{|c|}{ Reason for Transmittal (G) } & \multicolumn{1}{c|}{ Disposition (H) \& (II) } \\
\hline E. S. Q, D or N/A & 1. Approval & 4. Review & 1. Approved & 4. Reviewed no/comment \\
(see WHC-CM-3-5, & 2. Release & 5. Post-Review & 2. Approved w/comment & 5. Reviewed w/comment \\
Sec.12.7) & 3. Information & 6. Dist. (Receipt Acknow. Required) & 3. Disapproved w/comment & 6. Receipt acknowledged \\
\hline
\end{tabular}

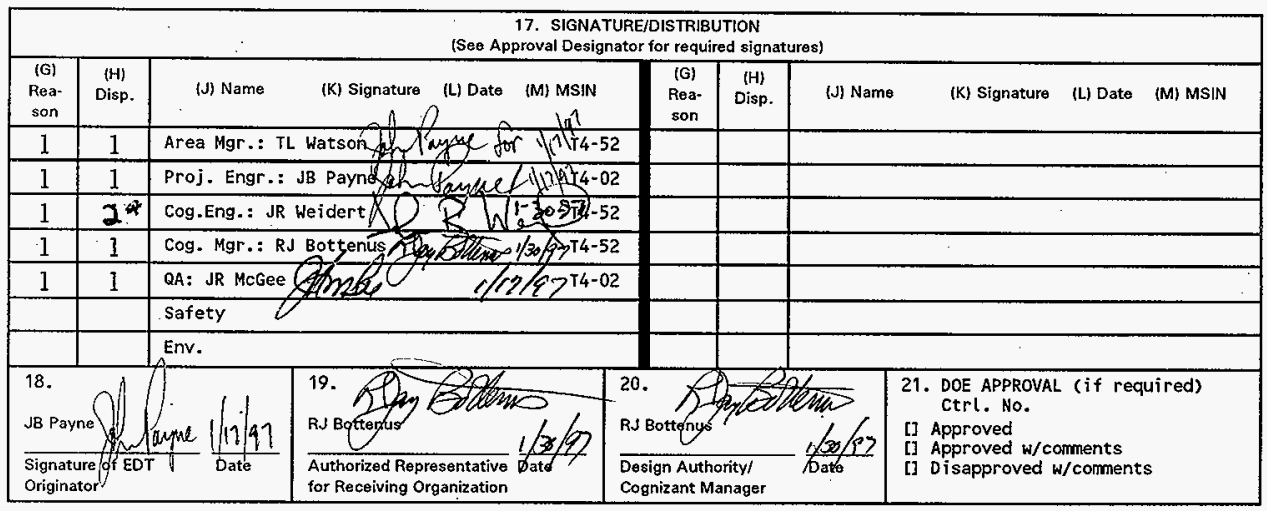

BD-7400-172-2 (05/96) GEF097

* SD HeadsR " PAgination requires on all
Pagzs 


\title{
W-026 Acceptance Test Plan \\ Plant Control System Software \\ (SUBMITTAL \# 216)
}

\section{TL WATSON}

Flour Daniel Northwest, Inc., Richland, WA 99352-1050

U.S. Department of Energy Contract DE-AC06-87RL10930

\author{
EDT/ECN: 617311 UC: \\ Org Code: 04E00 Charge Code: P1JF18 \\ B\&R Code: 39EW3130020 Total Pages: 858 859 \&4s $2 / 14 / 47$
}

Key Words: WRAP 1, PCS, Software, Control, RTAP, NETCOM, PLC, AllenBradley, OIU, X-Terminal, Server, Program, LCU

Abstract: Acceptance Testing of the WRAP 1 Plant Control System software will be conducted throughout the construction of WRAP 1 with final testing on the glovebox software being completed in December 1996. The software tests wil1 be broken out into five sections; one for each of the four Local Control Units and one for the supervisory software modules. The acceptance test report will contain completed copies of the software tests along with the applicable test log and completed Exception Test Reports.

TRADEMARK DISCLAIMER. Reference herein to any specific commercial product, process, or service by trade name, trademark, manufacturer, of otherwise, does not necessarily constitute or imply its endorsement, recomendation, or favoring by the United States Government or any agency thereof or its contractors or subcontractors.

Printed in the United States of America. To obtain copies of this document, contact: WHC/BCS Document Control Services, P.O. Box 1970, Mailstop H6-08, Richland WA 99352, Phone (509) 372-2420; Fax (509) 376-4989.
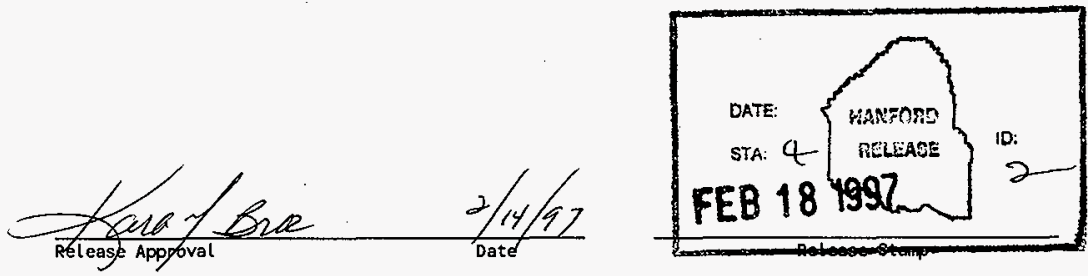
Supporting Document Coversheet HNF-SD-W026-ATP-027, Rev. 0

Page 2 of 2

ICOM is a trademark of Inoue Communication Equipment Corporation

WinLogic is a trademark of ICOM, Inc.

Allen-Bradley is a trademark of Allen-Bradley

HP is a trademark of Hewlett-Packard Company

cc:MAIL is a trademark of cc:Mail, Inc. a subsidiary of Lotus Development Corporation 
Systems Interface Inc. Acceptance Test Plan

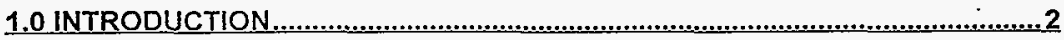

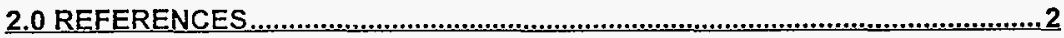

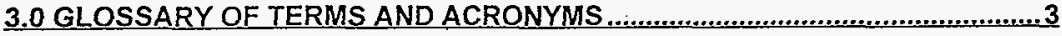

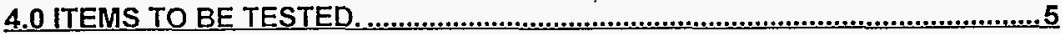

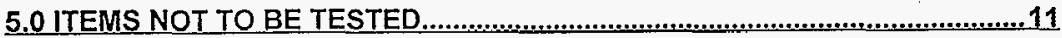

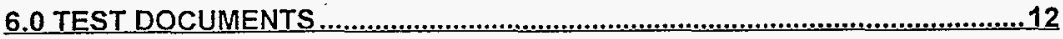

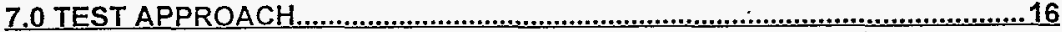

8.0 SUSPENSION CRITERIA AND RESUMPTION REQUIREMENTS _...............19

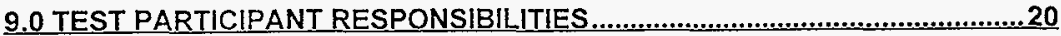

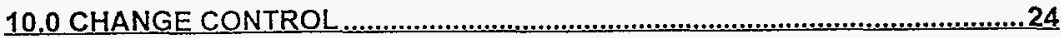

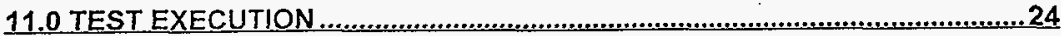

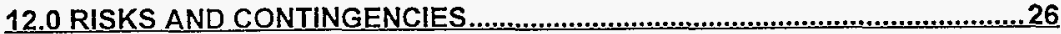

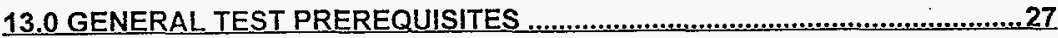

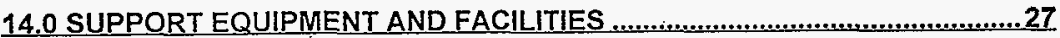

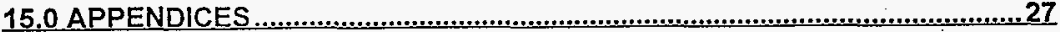


HNF-SD-W026-ATP-027, Rev. 0 Paḡe 2

Systems Interface Inc.

Acceptance Test Plan

\subsection{Introduction}

This document is to establish a procedure to execute and document all testing necessary for and as required by project criteria for the Waste Receiving and Proecessing (WRAP) facility.- The plan presents several sections that describe each aspect of acceptance testing. Technical terms and frequently used acronyms are listed followed by a brief introduction to acceptance testing. An overview of the testing method is provided, followed by descriptions of the required test documents and the suggested test participants along with their role in testing. A test scenario is proved and includes rules for executing test procedures, the criteria used to pass or fail a test, and the requirement for stopping and resuming testing. Additional testing constraints including Safety, Schedule, Facility. and Organization responsibilities are listed. References are also provided for source materials.

This test plan is designed to support the requirements of the contract specification sections. The contract specification section will take precedence in any discrepancy between this test plan and any contract specification.

This test plan may not anticipate all contingencies present in acceptance testing. Appropriate changes in test methods, procedures, documentation. or any other testing item that are required to facilitate testing and that are consistent with contract specifications and are agreed to by Both Buyer and Seller may be made during testing.

\subsection{References}

Raytheon Specifications for Hanford WRAP Module 1 Project:

Section 13461, "Plant Management System Hardware", Oct 1993.

Section 13462, "Plant Management System Software", Oct 1994.

Section 01655 - Division 1 Specification ATP Requirements, Oct 1993. IEEE Standard 829-1983, "IEEE Standard for Software Test Documentation"

"WRAP 1 PMS Hardware Requirements" by Westinghouse Hanford Co.

"WRAP 1 PMS Software Requirements" by Westinghouse Hanford Co. 
Systems Interface Inc.

\section{Acceptance Test Plan}

\subsection{Glossary of Terms and Acronyms}

ATP Acceptance Test Procedure. The assembly of all documents required to complete a test of a particular device or software module.

Buyer The company purchasing an item. component, module. or assembly. Westinghouse Hanford Company is herein referred to as the "Buyer"

Cognizant The person designated as the primary test witness. This

Wltness person verifies that each test prcedure step is correctiy. executed and that the output received from each step matches the output expected from each step. This person is also authorized to resolve exceptions.

Exception Log The form used to record test step output that differs from the expected test step output.

FAT Factory Acceptance Test

GFE Government Furnished Equipment.

HATP Hardware Acceptance Test Procedure (The test procedure used for both factory and plant acceptance tests).

HBFATP Hardware Buyer Factory Acceptance Test Procedure

HBPATP Hardware Buyer Plant Acceptance Test Procedure

HSFATP Hardware Seller Factory Acceptance Test Procedure

HSPATP Hardware Seller Plant Acceptance Test Procedure

ICF KEH ICF Kaiser Engineers Hanford Company

LLW L Low Level Waste

PCS Plant Control System

PMS Plant Management System

Regression Test Testing resulting from changing a test procedure in a way that affects other test procedures so that the affected test procedures must also be rerun.

Seller

The company or organization producing an item. component module or assembly which must be tested. 
HNF-SD-W026-ATP-027, Rev. 0 Pag̣e 4

Systems Interface Inc.

\section{Acceptance Test Plan}

PCL Construction Services Inc. and its subcontractors are herein referred to as the "Seller".

SATP Software Acceptance Test Procedure (The test procedure used for both factory and plant acceptance tests).

SBFATP Software Buyer Factory Acceptance Test Procedure

SBPATP Software Buyer Plant Acceptance Test Procedure

SSFATP Software Seller Factory Acceptance Test Procedure

SSPATP Software Seller Plant Acceptance Test Procedure

Test Director The person designated to facilitate and manage testing.

Test Operator The person designated to prepare equipment for testing and perform Test Procedures.

Test Plan The overview document which describes how testing will be performed. (This document).

Test Report The collection of documents created when a Test Procedure is run.

Test Review A meeting held before each test begins to discuss test objectives, test methods, safety precautions, and other items that will facilitate testing.

Test Recorder The person designated the distribute test information to participants and to assembly final test documents.

Test Witness A person designated to witness testing and sign off after successful test procedure completion. This person does not sign off individual test steps or resolve test exceptions.

TRU_TransUranic Waste

WRAP Waste Receiving And Processing

WLAN . WRAP Local Area Network 


\section{Systems Interface Inc.}

\section{Acceptance Test Plan}

\subsection{Items to be tested.}

All products supplied by the Seller under Specification Sections 13406, 13407,13461 , and 13462 will be covered under this acceptance test plan and are listed below. A seller and Buyer factory acceptance test (SF, BF) along with a seller and Buyer plant acceptance test (SP, BP) will be executed for a test procedure generated for each logical item or group listed.

Hardware Acceptance Tests

\begin{tabular}{|c|c|c|}
\hline $\begin{array}{c}\text { HATP } \\
\#\end{array}$ & Equipment Description & $\begin{array}{c}\text { Equipment } \\
\text { ID }\end{array}$ \\
\hline 1. & SHIPPING/RECEIVING/NDANDE LOCAL CONTROL UNIT & CNR-12-101 \\
\hline 2. & LLW PROCESSING LOCAL CONTROL UNIT & CNR-12-102 \\
\hline 3. & TRU PROCESSING LOCAL CONTROL UNIT & CNR-12-103 \\
\hline 4. & HVACIUTILMONS LOCAL CONTROL UNIT & CNR-12-104 \\
\hline \multirow[t]{6}{*}{5.} & OPERATOR CONTROL STATIONS including: & \\
\hline & A. NOE OPERATOR CONTROL STATION \#1 & CNS-12-101 \\
\hline & B. NDE OPERATOR CONTROL STATION \#2 & CNS-12-102 \\
\hline & C. TRANSPORT/NDA OPERATOR CONTROL STATION & CNS-12-103 \\
\hline & D. TRANSPORT/NDA OPERATOR CONTROL STATION & CNS-12-104 \\
\hline & E. DISPATCH OPERATOR CONTROL STATION (GFE) & CNS-12-105 \\
\hline \multirow[t]{3}{*}{6.} & DMS CENTRAL PROCESSOR including: & CPU-12-109 \\
\hline & A. DMS DISK DRIVE UNIT & DRV-12-109 \\
\hline & B. DMS SYSTEM TERMINAL & TE-12-109 \\
\hline \multirow[t]{2}{*}{7.} & PCS DATABASE SERVER including: & CPU-12-110 \\
\hline & A. PCS SYSTEM TERMINAL & $T E-12-110$ \\
\hline \multirow[t]{10}{*}{8.} & GLOVEBOX PROCESS WORKSTATIONS & \\
\hline & A. LLWENTRY G.B. PROCESS WORKSTATION & OIU-12-103A \\
\hline & B.LLW SORTING G.B. PROCESS WORKSTATION & OlU-12-1038 \\
\hline & C. LLWEXIT G.B. PROCESS WORKSTATION & OlU-12-103C \\
\hline & D. TRU ENTRY G.B. PROCESS WORKSTATION & OIU-12-104A \\
\hline & E. TRU SORTING G.B.PROCESS WORKSTATION & OIU-12-104B \\
\hline & F. TRU COMPACTED EMPTY DRUM LOADOUT WORKSTATION & OIU-12-104C \\
\hline & G. TRU LOADOUT GLOVEBOXES & OIU-12-104D \\
\hline & H. LLW RWM OPERATOR WORKSTATION & OlU-12-105B \\
\hline & 1. TRU RWM OPERATOR WORKSTATION & OIU-12-106B \\
\hline
\end{tabular}


HNF-SD-W026-ATP-027, Rev. 0 Page 7

\section{Systems Interface Inc.}

\section{Acceptance Test Plan}

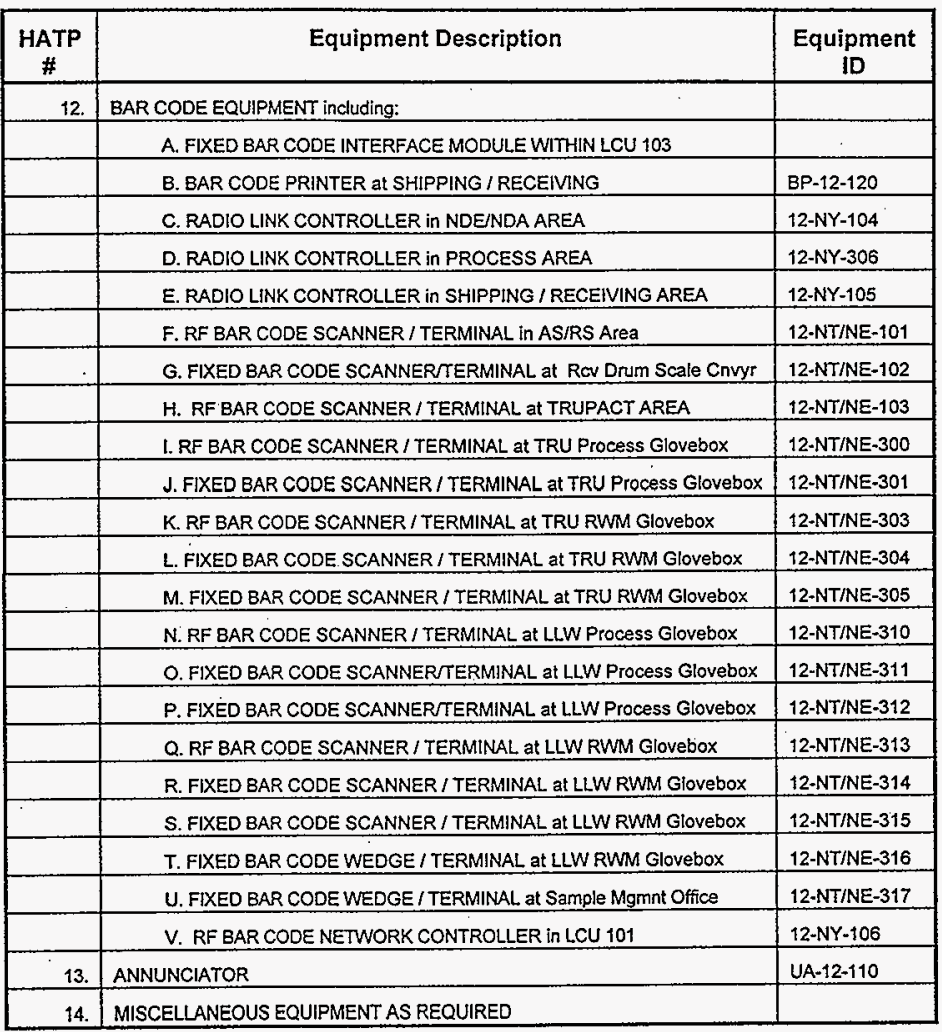


HNF-SD-W026-ATP-027, Rev. 0 Page 8

Systems Interface Inc.

Acceptance Test Plan

HATP Notes:

The test procedures for HATP items \#5, 6, 7, 8 (Operator Control Stations) will only include equipment supplied by Systems Interface Inc.

The Bar Code System and annunciator systems are not part of specification section 13461/13462 and, technically, not part of the acceptance test requirement. They are included here and will be tested for completeness. The tests performed for these items within this acceptance test will meet the test requirements found in specification sections 13406 and 13407. 


\section{Systems Interface Inc.}

\section{Acceptance Test Plan}

\section{Software Acceptance Tests}

\begin{tabular}{|c|c|c|}
\hline $\begin{array}{c}\text { SATP } \\
\#\end{array}$ & Software Process / Module Description & $\begin{array}{l}\text { Software Detail } \\
\text { Design Section }\end{array}$ \\
\hline \multirow[t]{5}{*}{1.} & Receiving & 7.1 \\
\hline & A. Receiving Dock & $\underline{711}$ \\
\hline & B. Drum infeed Convevor A & 7.1 .2 \\
\hline & C. Drum Scale Convevor A & $\underline{713}$ \\
\hline & D. Drum infeed Conveyor 8 & 7.1.6 \\
\hline \multirow[t]{3}{*}{ 2. } & Shipoing & $\underline{71}$ \\
\hline & A, Dum Scale Conveyor B & 2.1 .4 \\
\hline & B. Drum Discharge Convexor. & $\mathbf{Z 1 . 1 1}$ \\
\hline 3. & Autostacking / Rectrieving System & 7.1 .5 \\
\hline \multirow[t]{5}{*}{4.} & Shipping/Receiving/NDE/NDA Internal Transport & 7.1 \\
\hline & A. Drum Storage Carousel & 7.1 .7 \\
\hline & B. Airlock \& Transfer Conveyors & 7.1 .8 \\
\hline & c. Background Drum Storage Conveyors & 7.1 .9 \\
\hline & D. Empty Drum Infeed Conveyor & 7.1 .10 \\
\hline \multirow[t]{6}{*}{5.} & NDE/NDA Analysis & 7.1 \\
\hline & A. DrUm NDE & 7.1 .12 \\
\hline & B. PAN Systems & 7.1 .13 \\
\hline & C. GEA Systems & 7.1 .14 \\
\hline & D. BWAS & 7.1 .15 \\
\hline & E. BOXNDE & 7.1 .16 \\
\hline 6. & Shipping / Receiving / NDE / NDA Supervisory Control & $\underline{7.1 .17}$ \\
\hline \multirow[t]{4}{*}{ Z. } & Process Area Internal Transport & $7 . \underline{2}$ \\
\hline & A. Airlock \& Transfer Conveyors & 7.2 .1 \\
\hline & B. RW Drum Carousel & 7.2 .3 \\
\hline & C.Emply Drum Convevor & 7.3 .2 \\
\hline \multirow[t]{6}{*}{$\because 8$} & LLW Process Glovebox & 2.2 \\
\hline & A. LLW Lift Tables & 7.2 .2 \\
\hline & B. Entry Glovebox & $7,2,4$ \\
\hline & C. Sorting Glovebox & $\underline{7.2 .5}$ \\
\hline & D. Supercompactor & 7.2 .6 \\
\hline & E. Exit Glovebox & 72.7 \\
\hline
\end{tabular}


Systems Interface Inc.

\section{Acceptance Test Plan}

\begin{tabular}{|c|c|c|}
\hline$\frac{\text { SATP }}{\#}$ & Software Process / Module Description & $\begin{array}{l}\text { Software Detail } \\
\text { Design Section }\end{array}$ \\
\hline$\because 9$ & LLWW RWM Glovebox & 7,28 \\
\hline$\because 10$. & LLW Supervisery Control & 7.29 \\
\hline \multirow[t]{6}{*}{ *a** 11.} & IRUProcess & $\underline{7.3}$ \\
\hline & A. Entry Glovebox & $\underline{7.3 .3}$ \\
\hline & B. Sorting Glovebox & $7,3,4$ \\
\hline & C. Empty Drum Compact Glovebox & $\underline{7.3 .5}$ \\
\hline & D. Emoty Drum Load-out Glovebox & 7.3 .6 \\
\hline & E. Waste Load-out Glovebox & $\underline{7.3 .7}$ \\
\hline$\approx 12$. & IRURW Glovebox & $\mathbf{Z 3 . 8}$ \\
\hline 13 & IRU Supervisory Control & 7,39 \\
\hline 14. & Fixed Bar Code Processing & $\underline{7.3 .10}$ \\
\hline \multirow[t]{5}{*}{15.} & Utility Systems & $\underline{7.4}$ \\
\hline & A. HVAC & 7.4 .1 \\
\hline & 3. HVAC Supervisory Control & $\underline{7.4 .4}$ \\
\hline & C. Health Physics Monitors & 7.4 .2 \\
\hline & D. Faccilities Miscellaneous & $\underline{7.4 .3}$ \\
\hline \multirow[t]{7}{*}{16.} & NetCom on PCS Sever, network system communication including; & $\underline{7.5}$ \\
\hline & A. Automated Guided Vehicle (AGV) & 7.5 \\
\hline & B. Data Management System (DMS) & $\underline{7.5}$ \\
\hline & C. AutoStacking / Retrieving System (AS/RS) & $\underline{7.5}$ \\
\hline & D. Packet Assay Monitor (PAM) & $\underline{7.5}$ \\
\hline & E. Passive Active Neutron Assay Systems (PAN) & $\mathbf{7 . 5}$ \\
\hline & F. Gamma Energy Assay Systems (GEA) & $\underline{7.5}$ \\
\hline \multirow[t]{2}{*}{$\underline{17}$} & RF Telnet (on PCS Server. communication with all RF Barcode Terminals) & $\underline{7.6}$ \\
\hline & (including communication to 12-NT/NE-101,103,300,303.310,313) & \\
\hline \multirow[t]{3}{*}{18.} & SerComt (Serial Communications Co-processer located within LCU101) & $\underline{7.7}$ \\
\hline & A. Drum Scale Weight Transmitters (A \& B) & 7.7 .1 \\
\hline & B. $80 x$ Conveyor Scale Weight Transmitter & $\underline{7.7 .1}$ \\
\hline \multirow[t]{3}{*}{19.} & Sercom2 (Serial Communications Co-processor located within LCU101) & 7.8 \\
\hline & A. Drum Transfer Conveyor Weight Transmitters (A \& B) & $\mathbf{7 . 8 . 1}$ \\
\hline & B. Lift Table Serve Motor Conirollers & $\mathbf{7 . 8 . 2}$ \\
\hline
\end{tabular}


HNF-SD-W026-ATP-027, Rev. 0 Pağe 11

Systems Interface Inc.

Acceptance Test Plan

\begin{tabular}{|r|c|c|}
\hline $\begin{array}{c}\text { SATP } \\
\#\end{array}$ & Software Process / Module Description & $\begin{array}{c}\text { Software Detail } \\
\text { Design Section }\end{array}$ \\
\hline 20 & SerCom3 (Serial Communications Co-processor located within LCU101) & 7.9 \\
\hline & A. Liff Table Weight Transmitters & 7.9 .1 \\
\hline & B.Sor Table Servo Motor Controllers & 7.9 .2 \\
\hline & C. Lift Table Servo Motor Controllers & 7.9 .3 \\
\hline 21. & SerCom4 (Serial Communications Co-processor located within LCU104) & 7.10 \\
\hline & A. HVAC Controller & 7.101 \\
\hline 22. & Misc. Diagnostic and Troubleshooting programimed features & Various \\
\hline
\end{tabular}

SATP Notes:

The software acceptance tests listed above follow the functional requirements of the systems as listed in the specifications and Detail Software Design Submittal. As each module is tested, the associated communications links will also be tested.

*** corresponds to test procedures currently covered under separate "Integrated Testing" (see below)

\subsection{Items Not to be Tested}

The test procedures for HATP items \#5E, 9A, and 9B (Government Furnished Equipment) will be supplied by Systems Interface but execution of the tests along with Exception Resolution will be the responsibility of the Buyer.

Interface to equipment supplied by others (such as the Supercompactor) will be tested to the point of verifying that the data is appropriately received by that equipment and specifically excludes testing the functionality of that equipment. This equipment includes (among others) the Supercompactor, Gloveboxes, BWAS, NDE, GEA, PAN, SIE, DMS software, Weight transmitters, Health Physics monitors, HVAC controller, Pneumatic Valve Manifolds, Bagless Transfer Port Controllers, AGV, Lift and Sort Tables, Conveyors, Drum Storage Carousels, and Packet Assay Monitor equipment. Systems Interface will work with the vendors of this equipment, as much as possible, to help validate their equipment functionality during the plant acceptance test process. - Separate integrated testing may occur under a different test plan. Test procedures covered under these integrated tests may replace or supercede those 
HNF-SD-W026-ATP-027, Rev. 0 Paḡe 12

\begin{tabular}{|l|l|l|}
\hline \multicolumn{3}{|c|}{ Systems Interface Inc. } \\
\hline & Acceptance Test Plan & \\
\hline
\end{tabular}

covered within this test plan. In those cases, the Software Acceptance Test Procedures called for under this plan will not be created and they will be covered within the integrated test procedures. The glovebox process lines are currently part of separate integrated testing. - Software Acceptance Tests \#8 through \#14 (shown with *** in the SATP table) are currently covered under separate integrated testing. Buyer approval is required for these omissions.

\subsection{Test Documents}

Several documents are used to record test information. This section describes test documents and how these documents are assembled to record test results.

The documents used to support testing are:

\begin{tabular}{cl}
\hline$\cdot$ & Test Plan \\
\hline$\cdot$ & Test Procedure \\
\hline$\cdot$ & Test Report \\
\hline$\cdot$ & Test Procedure Cover Sheet \\
\hline- & Test Procedure Data Sheets (when applicable) \\
\hline$\cdot$ & Test Log \\
\hline$\cdot$ & Test Procedure Exception Log \\
\hline$\cdot$ & Master Test Procedure Exception List \\
\hline$\cdot$ & Test Document Package (TDP)
\end{tabular}

Document requirements and examples of selected test documents are provided in the Appendix "Examples of Test Documents". The primary test documents are described below.

\subsection{Test Plan}

This document is the test plan and it describes the purpose for testing. the types of test(s) to be performed, and generally, how the test procedures will be performed, witnessed, approved, along with resolution of exceptions.

Each item called out for testing in the specification sections will be tested. The type of test used to verify that specification requirements are met will vary depending on the nature of the item. Many items can be tested via simple inspection. Other items will require detailed. stepby-step test procedures. 


\section{Systems Interface Inc.}

\section{Acceptance Test Plan}

\subsection{Test Procedures}

Each item, attribute, property, or feature to be tested represents a "Test Case". Test procedures will be created to include all "test cases". Test procedures describe test case objectives, a list of the items to be tested, references, and test procedure steps. Test procedure steps describe in a step-by-step manner the actions taken and the verifications that will be made to complete testing. To reduce paperwork and simplify testing, where appropriate, multiple related "test cases" should be included in a single test procedure.

Each test procedure contains introduction sections describing the techniques used to perform the test(s), the prerequisites required for each test, special equipment required to complete the tests, and indicates the general safety precautions required during testing.

This test plan calls for both Hardware and Sofware Test Proecedures. The Hardware Acceptance Test Procedures involve testing individual components within an assembly to ensure proper operation in accordance with specification requirements. Equipment inspections may also occur during hardware testing to ensure compliance with specifications. This testing can also be called Functional Testing.

The Softtware Acceptance Test Procedures involve both performance and integrated testing. The performance tests ensure all items of an assembly work together. Integrated testing demonstrate that all subassemblies of a larger assembly (such as an entire glovebox) operate as a system in accorance with specification requirements. Normal operation, interlock, safety, and error recovery features are to be tested in accordance with specification requirements.

All test procedures will include references to a Buyer supplied "traceability matrix". The traceability matrix directly associates each test procedure step with the relevant specification section requirement and is used by the Buyer to verify that each contract specification is addressed by a test procedure. Some test procedures will also include a "testing tree". The testing tree provides an overview of the testing to be performed. The testing tree lists every test procedure that will be run, and the order for running these procedures under the test plan. 
Systems Interface Inc.

Acceptance Test Plan

\subsection{Test Reports}

During testing, a test report will be prepared for each test procedure executed. Test Reports will contain the following items:

Test procedure Cover Sheet

The Test Procedure Cover Sheet is used to record testprocedure specific information during testing. A completed cover sheet is required for each test procedure.

\section{Test Procedure}

Each test step requiring verification will be initialed by the cognizant test witness and a copy of the entire test procedure signed by all relevant witnesses will be included in the test report.

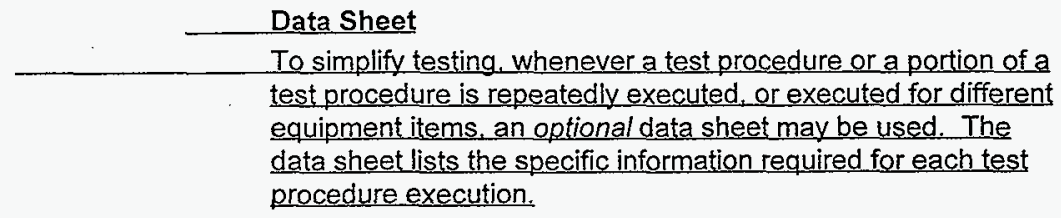

For example, if a test is conducted for four identical devices. only one test procedure is written and a data sheet is attached referencing the equipment tag numbers and other informationfor each device.

Test Procedure Supporting Documents.

Test Procedure Specific Supporting documents are optional and are used when additional information is required to complete test procedures. Examples of supporting documents would be equipment operator manuals or guides, calibration values, and other similar documents that can be used to support testing. When included in a test report, supporting documents should be 
Systems Interface Inc.

\section{Acceptance Test Plan}

labeled with the associated test procedure number and each supporting document page should be sequentially numbered.

\section{Test Procedure Exception Log}

A Test Procedure Exception Log is used whenever actual output differs substantially from expected output, resulting in test failure.

A test exception occurs when actual output differs substantially from expected output in a way that materially affects test results. For example, a port door not opening on initiation of an "opening sequence" during testing would be a test exception. Every time a test exception occurs, it is recorded on a Test Procedure Exception Log along with the planned resolution inifialed by the cognizant test witness.

After testing has been completed, a master list of all unresolved test exceptions is created. The exception list is included in the final test documentation.

\section{Test $\log$}

During testing, a logbook will be prepared to document test results. The test $\log$ serves as a repository of general testing information. Typical log entries will include the date and time the log entry is made, the test procedure being performed, and explanatory comments. An entry is made in the log each time testing using a particular test procedure begins. Test exceptions, unusual test results, reasons for canceling or delaying testing and other similar information is placed in the test log to provide a comprehensive record of testing.

\section{Test Document Package}

The final testing document is often called a "Test Document Package" or "TDP" and is an assembly of all testing documents relevant to the test of a particular assembly, such as the LLW Process Glovebox line. 
Systems Interface Inc. Acceptance Test Plan

To produce a TDP, the test plan, the relevant test procedures, all test reports, the test $\log$, and the exception list for a particular type of testing are assembled. A cover sheet, a table of contents a brief introduction explaining the objectives and results of the test, and any other supporting documents are added to produce the TDP.

Appendix "Examples of Test Documents". lists the suggested contents for each testing document, and provides examples of selected testing documents.

To reduce the number of TDPs created, where appropriate, the test procedures for different levels of testing may be grouped together as separate sections in a single TDP.

\subsection{Test Approach}

All tests will include sufficient detail to ensure that all parts of the PMS as provided by the seller (Systems Interface) are functional as specified. All tests must be based upon a test plan and use test procedures submitted to the Buyer and approved. The equipment to be tested is to be completely assembled by the seller and have undergone any preliminary inspections.

The Hardware Acceptance Test Procedures (HATP) involve testing individual components within an assembly to ensure proper operation For the Local Control Units, this includes the point by point testing of all Inputs and Outputs. Additionally, the Hardware Acceptance Tests will verify that the supplied equipment meets specification requirements via a referenced Requirements Matrix. This testing can also be called Functional Testing. Buyer's presence during this phase of testing is optional, at the Buyer's discretion. 
The Softtware Acceptance Test Procedures (SATP) involve both performance and integrated testing. The performance tests ensure all items of an assembly work together. Integrated testing demonstrate that all subassemblies of a larger assembly (such as an entire glovebox) operate as a system in accorance with specification requirements. Normal operation, interlock, safety, and error recovery features are to be tested in accordance with specification requirements. This testing includes all PCS software and PCS system interfaces including PLC ladder logic_modules, PCS Server RTAP, PCS Server RF Telnet, PCS Server NetComm, along with the application software these modules are executing on.

All testing will be executed for both the seller (internal) and Buyer (predelivery) at both the seller's Factory and Buyer's Plant Site. Thus, the PCS system will undergo a total of eight tests, Hardware Seller Factory (HSF), Hardware Buyer Factory (HBF), Software Seller Factory (SSF), Software Buyer Factory (SBF), Hardware Seller Plant (HSP), Hardware Buyer Plant (HBP), Software Seller Plant (SSP), and Software Buyer Plant (SBP). The Seller tests are internal "dry-runs" prior to formal witnessing by a Buyer's representative and do not need any approval beyond the usage of a Buyer approved test procedure. These tests will use the same test procedures as for the formal Buyer tests except that witness(es) used for this testing will be seller supplied cognizant engineers and no Buyer approval is necessary. It is possible (and desirable by the seller, SII) for a Buyer's representative to monitor the seller testing and make informal comments in order to expedite approval and execution of the formal Buyer tests. If and when agreed to by the buver, some Hardware Acceptance. Test Procedures may only be performed at the seller's factory.

For the factory tests, simulation software will be obtained from the network host system vendors for integration into this these procedures, when possible. If these simulation packages are unavailable or can not be delivered without affecting test schedules, simulation software will be developed for those network host systems as necessary by the seller (SII) to facilitate communications and control sequence testing. The simulators will only provide verification that interface commands have "reached" system in the proper format and allow for rudimentary control sequencing of responses back. These simulators may consist entirely of a 


\section{Systems Interface Inc.}

\section{Acceptance Test Plan}

communications routine (' $\mathrm{C}$ ' program) residing on the network monitoring the pre-defined TCP port addresses for commands and / or data, logging the communication and responding to the commands. The simulators will not be formally tested beyond peer reviews and internal factory tests performed by the seller (Systems Interface Inc). Major systems requiring communication simulation software include the AGV, AS/RS, PAM, DMS, PAN, GEA, and SIE. Currently, simulation software will be generated by seller for the PAN and GEA systems. The DMS will have simulation software generated by the Buyer which includes PCS $\leftrightarrow$ DMS $\leftrightarrow$ SIE status. The AGV, AS/RS, and PAM system simulation software may be provided by those vendors. The discrete $1 / O$ control (such as NDE) simulation will be performed through separate software modules residing. in the LCU's (PLC ladder). All simulation source code developed by the Seller (SII) will be provided to the Buyer for functional verification.

Additional test "tools" will be developed by the seller for the PCS server. These tools. will facilitate testing by providing easy access to database entries for bar code values read, I/O point status, network communication packets, etc. These tools will be referenced in the Software Acceptance Test Procedures. These tools will become part of the delivered software package for future Buyer maintenance functions.

A test log will be used to provide a chronological record of relevant details about the execution of tests. The test log will identify items being tested with version / revision levels, the attributes of the environment such as memory and resources available, and any anomalous events with information both before and after the unexpected event.

Note that many tests involve working with 120 Volt $A C$ power which is potentially hazardous unless appropriate safety precautions are taken. This includes basic knowledge of electricity and awareness of whether a circuit or wire is energized before beginning work with or near any exposed electrical wiring or components. 
Systems Interface Inc.

\section{Acceptance Test Plan}

\subsection{Suspension Criteria and Resumption Requirements}

The Test Director needs to be informed IMMEDIATELY if problems are encountered with a procedure, safety or otherwise.

If a procedure cannot be performed as written, the test will be stopped, the equipment will be returned to a safe configuration, and the Test Director will be informed that the procedure cannot be performed as written, and revision or retest is required.

The Test Director will make a determination as to whether the problem is Minor or Significant. The Test Director will get approval from the authorized Buyers cognizant witness before classifying a problem as Minor or Significant and possibly continuing testing.

A Minor problem would be anything that can be resolved with as "ASBUIL.T" notes in the test procedure and might be such problems as typographical errors, missing steps, or parameters incorrectly set.

Minor problems do not require an exception report to be generated and resumption of the test can occur immediately.

A Significant problem requires an exception report to be generated and the test will be stopped until the change is approved. This does not prevent the running of another portion of the test unaffected by the problem. Changes made to software may require an impact analysis to determine what other software modules and / or test procedures may have to be re-tested to account for possible secondary effects. This analysis (or re-test list) will be approved by the Buyer's authorized representative witnessing and accepting successful test execution before test resumption may occur. The test exception report will contain this information and provide signatures authorizing disposition.

Certain tests need to be completed in their entirety for a successful execution. These tests will be identified as such in the "Safety, Precautions, and Limitations" section of each procedure.. If a test procedure is not labeled "Needs to be completed in full without interruption for a successful test", then the test procedure can be interrupted at any step and restarted at a later time without having any impact on those test steps occurring later. 
Systems Interface Inc.

\section{Acceptance Test Plan}

\subsection{Test Participant Responsibilities}

General

Each company or organization participating in the specified test will designate personnel to assume the responsibilities and duties as defined herein for their respective roles. The personnel shall become familiar with this document and with the details of the specified test to the extent that they can perform their assigned duties.

Test Director

A cognizant engineer supplied by the seller's subcontractor (Systems interface)

Coordinates testing with all participants and directs testing.

Acts as a liaison between the participants in the testing.

Is responsible for creation of all testing documents.

Distributes the approved testing schedule before start of testing.

Schedules and conducts a pretest kickoff meeting with the test participants before the start of testing when necessary.

Notifies the persons performing and witnessing the test at least fourteen (14) days before the start of pre-shipment and performance testing seven (7) days in advance for random assembly inspections, and two (2) days advance notice for all other tests.

Schedules a dry run when necessary (the seller tests).

Notifies affected parties when a change is made to the testing schedule.

Requests in writing from the owner those services, materials, or equipment that have been designated as being supplied by others.

Takes necessary action to clear exceptions to the test. This includes consulting with the cognizant witness and receiving concurrence describing test exceptions as minor or significant.

Confirms that field testing and inspection of the system or portion thereof to be tested has been completed. 


\section{Systems Interface Inc.}

\section{Acceptance Test Plan}

Stops any test which, in his judgment, may cause damage to the system or put the safety of people at risk until the problem has been resolved.

After verifying that there is no adverse impact, may alter the sequence in which systems or subsystems are tested.

Ensures that required environmental conditions are maintained.

If a test is suspended for a period of time or is completed, ensures that the system is left in a safe mode.

Before restarting a suspended test reverifies the test prerequisites.

Initiates any documentation necessary to record required changes to the test which are incorporated into the final TDP.

Reviews recorded data, discrepancies, and exceptions.

With concurrance of the cognizant test witness, obtains information or changes necessary to clear or resolve objections during the performance of the test.

Signs Execution Test and Approval page when test has been performed.

Signs Exception form when an exception has been resolved.

Obtains required signatures on the original documentation prior to reproduction and distribution.

Cognizant Witness

A Cognizant engineer provided by the Buyer.

Witness the tests.

Review the results of testing.

Provides input and expert advice to resolve test exceptions.

Initials each test step of the Test Procedure Field copy as it is completed, or on a data sheet when provided.

Records test instrument identification numbers and calibration expiration dates. 
HNF-SD-W026-ATP-027, Rev. 0 Page 22

\section{Systems Interface Inc.}

\section{Acceptance Test Plan}

Authorized by the Buyer to approve:

1) starting. stopping pausing and resuming test operations as requested by the Test Director.

2) initials each test step

3) test completion.

4) classification of test problems as Minor or Significant as determined by the Test Director.

5) planned resolutions of test exception reports.

6) final dispositions of test exception reports.

\section{Witness(es), Inspector}

Additional Cognizant engineer(s) provided by the Buyer.

Witness the tests.

Review the results of testing.

Provides input and expert advice to assist in the resolution of test exceptions.

Authorized by the Buyer to approve:

1) Final test completion.

Recorder (possibly combined with a Witness or Operator)

Verifies that the test procedure used is the current revision.

Prepares a field copy of the relevant test procedures for use in testing.

Records objections and exceptions on the Test Procedure Exception Log.

Creates Final Exception List.

Updates test procedures due to changes made during testing. Assembles test documents to produce the Test Document Package. 
Systems Interface Inc.

\section{Acceptance Test Plan}

Submits the completed TDP to the Test Director. The Test Director transmits a copy to the Buyer when the test has been accepted and exceptions closed.

After test is finished, assigns sequential alohanumeric page number to test documents created during testing (i.e. Test Reports, Test Procedure Exception Logs, data print-outs, etc.) Records appropriate TDP page numbers in the Table of Contents.

Checks and dates each test step on the field copy as it is completed. Records test data as directed by the Test Witnesses. The check box at the ar right of the procedure steps indicate that the step has been completed, not that the test was successful or not.

Records comments and any other relevant information in the Test Log as directed by Test Director or Test Witnesses.

Signs Test Procedure indicating the name of the Recorder.

Test Operator (maybe combined with the Test Director)

A cognizant engineer supplied by the seller. Multiple test operators may conduct testing.

Performs the test under the direction of the Test Director.

Provides labor, equipment, and test instruments required for performing tests which have not been designated as being provided by others.

Requests in writing, from various the suppliers, those services. materials, or equipment that have been designated as supplied by others.

Confirms that equipment required for performing test will be available at the start of testing.

Signs the Test Procedure Cover Sheet.

Signs the Test Procedure Exception Log. 


\subsection{Change Control}

All test documents will be covered under the Configuration Control Plan and Quality Assurance plans to ensure the latest versions are being used for the test procedures. Please reference these documents for further information.

\subsection{Test Execution}

Occupational Safety and Health

Individuals shall carry out their assigned work in a safe manner to protect themselves and others from undue hazards and to prevent damage to property and environment. Performance of test activities shall always include safety and health aspects.

\section{Test Process}

Testing starts when the test operator and witness(es) sign the Test Execution form and note in the test log that testing for procedure XXX has started. The log is used to keep a record of all testing events for each testing phase. Major events include starting and stopping of each test procedure, success or failure of execution, and Minor problems that are resolved during testing without generating a test exception report.

The test operator proceeds through prerequisites and setup, and witnesses concur that prerequisites have been satisfied and setup is correct.

Operator starts through the test procedure, with only the cognizant witness initialing the success or failure of each test case and the Recorder checking the steps off as they are completed.

If a test fails, the Test Director classifies the failure as a Minor or Significant problem, the Recorder notes this classification in the Test $\log$ and the cognizant witness signs the test log authorizing this classification.

A Minor problem would be anything that can be resolved with as "AS-BUILT" notes in the test procedure and might be such problems as typographical errors, missing steps, or parameters incorrectly set. Minor problems do not require an exception report to be generated and resumption of the test can occur immediately if the test procedure allows for it. 
Systems Interface Inc.

Acceptance Test Plan

A Significant problem requires an exception report to be generated and the test will be stopped until the change is approved. This does not prevent the running of another portion of the test unaffected by the problem.

Exceptions are processed by SII by indicating a planned resolution of the exception on the Exception Report form. The planned resolution may indicate an error in the procedure (e.g., missing setup requirement), failure of equipment, or possibly an error caused by GFE, or other cause outside control of SIl. If the cognizant witness accepts the planned resolution, the cognizant witness signs the Exception Report form authorizing Sll to affect repairs. If the cognizant witness disagrees with the planned resolution, the cognizant witness does not sign, and indicates their reason for the disagreement.

Once repairs or other disposition is complete, SIl completes the "Action Taken" section on the Exception Report form. SII and the cognizant witness sign the Exception Report accepting disposition of the problem, indicating that the test procedure is ready for retest. The cognizant witness may also indicate on the Exception Report form that regression testing is required. Regression testing is required in cases where modifications have been made that may affect the results of other test procedures. When an exception is completed, the exception entry is closed on the exception master log.

When all Exception Report forms have been signed off, indicating that a test procedure is ready for retest, the test operator and witness(es) sign a new Test Execution form and start the test at the appropriate place, as indicated in the test procedure's resumption requirements section.

When a test procedure has been executed without any exceptions outstanding, all witnesses sign the approval blocks under the "Disposition" section of the test procedure, indicating a successful test completion. All test output (including printouts, notes, or data files) are marked by date, time, procedure step, test execution number, and page number (if necessary) and are attached to the test execution form. 
Systems Interface Inc.

Acceptance Test Plan

For the Buyer factory and plant acceptance tests, SII and the cognizant witness sign the Test Execution form under "Test Acceptance" when all exceptions have been closed and the witness(es) have indicated that the test was successfully completed.

\subsection{Risks and Contingencies}

A major risk to completion of the testing effort would be the classification of all problems encountered in the testing effort as Significant, which requires exception reports to be completed. An exception report stops the current section of a test procedure until approval of the report dispositions and actions. This consumes a lengthy period of time and delay testing significantly, especially if the test requires extensive setup and completion without interruption.

The Minor problem classification with "AS-BUILT" corrections to the test procedure is the most expedient way to allow test continuation to occur for these problems. Minor problems will arise and interrupt the test process. If the problem can be fixed or resolved immediately and is insignificant to functionality of the system, it should not create an extensive amount of administrative paper trails. Note that proper documention of all AS-BUILT corrections will be performed no matter how test problems are classified (Minor or Significant).

Another important requirement to sucessful completion of testing is a single cognizant witness. Only one person should be authorized to approve each test step and resolve problems. If multiple sign-offs were required for each step or problem, test time would be extended a considerable amount, most likely to the point of affecting the overall test completion schedule.

Additionally, a mechanism needs to be in place to ensure timely resolution of ECNs generated during the test process. Numerous required specification changes will be discovered during the Seller Software Acceptance Tests and the Seller (Systems Interface) needs to be able to generate approvable ECN's quickly without having to traverse the formal RFI process which would delay test completions significantly. This requires a Buyer's representative (cognizant test witness) present during the Seller Tests to provide engineering consultation with determination of specification changes to be made and to approve the ECN's generated during the tests. 


\section{Systems Interface Inc.}

\section{Acceptance Test Plan}

\subsection{General Test Prerequisites}

In addition to the test pre-requisites listed in the individual test procedures, Inspection of the installation of the system component to be tested is required. The inspection will include as a minimum:

Inspection of all equipment to check for solid installation, secure wiring, safe environments, and possible damage to the equipment during shipping.

The systems to be tested have been inspected for safety.

All reference documents have been verified for the correct revision number and all changes have been noted.

The simulation software associated with the equipment is available, downloaded, and properly executing.

Power is available.

Associated lamps have been tested.

All necessary process elements are available for use and methods of disposal of spent process elements have been approved by the owner.

Voice communications are available between test.locations (if witnesses in multiple locations are required to complete a test).

The Buyer may also wish to inspect the equipment for specification compliance via the traceability matrix.

\subsection{Support Equipment and Facilities}

The Seller shall furnish all support equipment, services, and utilities

necessary to perform glovebox inspections and testing.

Typically inspections and functional testing will be performed at Seller's facilities. Software Acceptance Testing will be performed at the Seller's facilities as much as possible (through simulation) and completely on-site at Buyer's facility.

\subsection{Appendices}

A sample Hardware Acceptance Test Procedure along with test documents are attached. 
HNF-SD-W026-ATP-027, Rev. 0 Page 28

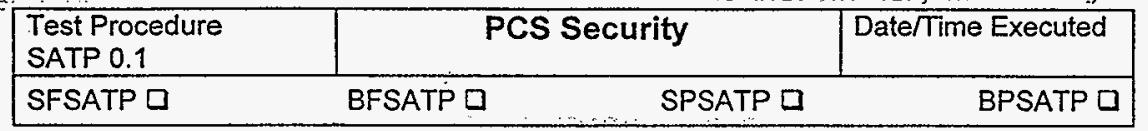

\section{Revision Status}

This test procedure is based on Specification Section 13462, Attachment 1, Revision 2, $8 / 15 / 94$ and has incorporated all of the applicable engineering changes received by and requests for information issued by Systems interface to date.

\section{Release/Revision Abstract:}

Pre-release approval review.

\begin{tabular}{|c|l|l|}
\hline $\begin{array}{c}\text { Release/Revision } \\
\text { Number }\end{array}$ & Abstract & $\begin{array}{l}\text { Release } \\
\text { Date }\end{array}$ \\
\hline $0-0 . x$ & Pre-release approval reviews & $7 / 25 / 95$ \\
\hline 1 & Formal Submittal & $3 / 22 / 96$ \\
\hline & & \\
\hline & & \\
\hline & & \\
\hline
\end{tabular}




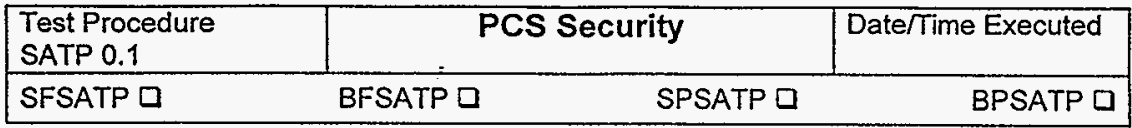

\section{Test Objectives}

This test procedure tests the PCS functionality for security.

This test procedure includes the following test cases:

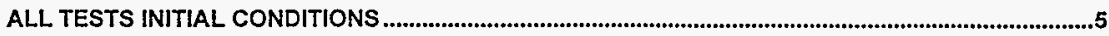

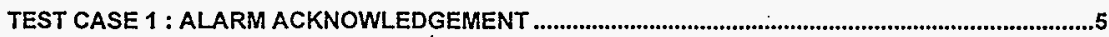

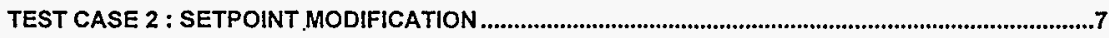

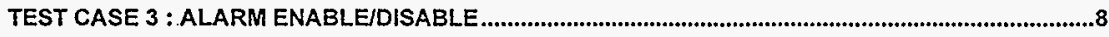

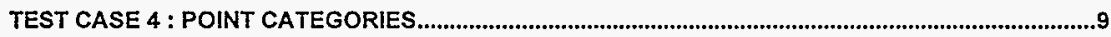


HNF-SD-W026-ATP-027, Rev. O Page 30

\begin{tabular}{|l|cc|c|}
\hline $\begin{array}{l}\text { Test Procedure } \\
\text { SATP } 0.1\end{array}$ & PCS Security & Date/Time Executed \\
\hline SFSATP $\square$ & BFSATP $\square$ & SPSATP $\square$ & BPSATP $\square$ \\
\hline
\end{tabular}

\section{WRAP Equipment Required}

The following lists the minimum equipment required to perform the tests as described by this procedure. Other equipment that is not mentioned here may be utilized to aid in the testing.

$\begin{array}{ll}\text { NDA OCS } 1 & 201-\text { CNS-12-103 } \\ \text { PCS Server } & 202-\text { CPU-12-110 }\end{array}$

\section{Test Equipment Required}

The following lists the minimum equipment required to perform the tests as described by this procedure. Other equipment that is not mentioned here may be utilized to aid in the testing.

none

\section{References}

1. Specification Section 13461

2. Systems Interface Test Plan

3. Systems Interface PLC Memory Maps

4. Systems Interface WRAP Facility Management System Network Communications Protocol Document

5. WRAP 1 Computer System Interface Definition Document, Rev. 0

\section{Safety Precautions}

1. Notify personnel prior to testing of special safety precautions and conditions during testing.

2. Prior to testing assure that Test Operators are familiar with the normal operation of the equipment being tested and are instructed in the operations to be performed.

3. Ensure that all affected equipment is properly installed and operating correctly.

4. Ensure that this test procedure has been thoroughly reviewed by all persons involved in the testing prior to beginning testing.

5. Please note that Revision 0 test procedures are initial draft test procedures. Revision 0 test procedures should be thoroughly reviewed prior to actual use.

6. Ensure that all persons involved with the test are familiar and have read the Systems Interface Test Plan, Latest Revision. 
HNF-SD-W026-ATP-027, Rev. 0 Page 31

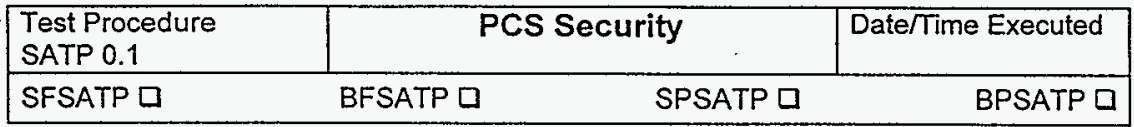

\section{Test Procedure Notes}

The next section contains the specific test procedures to be followed. The following notes pertain to all of the test procedures found herein.

1. For each test case there are a set of initial conditions which need to be met before that test case can begin. All of the initial conditions are given in step 0 .

2. All references to activating ( 1 ) and deactivating ( 0 ) VO are to be accomplished by using a PC or laptop and PLC software for the SFSATP, BFSATP and the SPSATP. For the BPSATP the plant equipment that is being interfaced to/controlled will be used to generate the required signals.

3. All references to sending and receiving NETCOM messages are to be accomplished using data entry and message monitoring screens on the PCS for the SFSATP, BFSATP and the SPSATP. The test participants can verify message transmissions by using the PCS message monitoring windows. For DMS messaging the DMS simulator can be used to transmit and check for receipt of messages if it is found to be feasable to do so.

For the BPSATP the plant equipment that is being interfaced to/controlled will be used to generate the required signals.

4. References to OCS screens are given in square [] brackets which contain the screen title. The operator will need to switch to the listed screen to verify the test step. For example, [NDE A] refers to the NDE A system screen and [NDE/NDA] refers to the NDE/NDA overview screen.

5. [Alarm Summary] refers to both the alarm summary screen and the alarm printer and the alarm $\log (\mathrm{s})$. As a minimum, the referenced screen must be checked to ensure that the step being tested has passed. The summary screen is located in a separate workspace which can be access via a button on the bottom of the OCS screen. The testing of the alarm handling (i.e. acknowledgment, printing and logging of alarms ) is in SATP 0.2.

6. SRM \# is the Software Requirements Matrix reference number. 


\section{All Tests Initial Conditions}

a All required equipment is powered up.

b The network is up and operational. Router is on, all net lines connected.

\section{TEST CASE 1 : Alarm Acknowledgement}

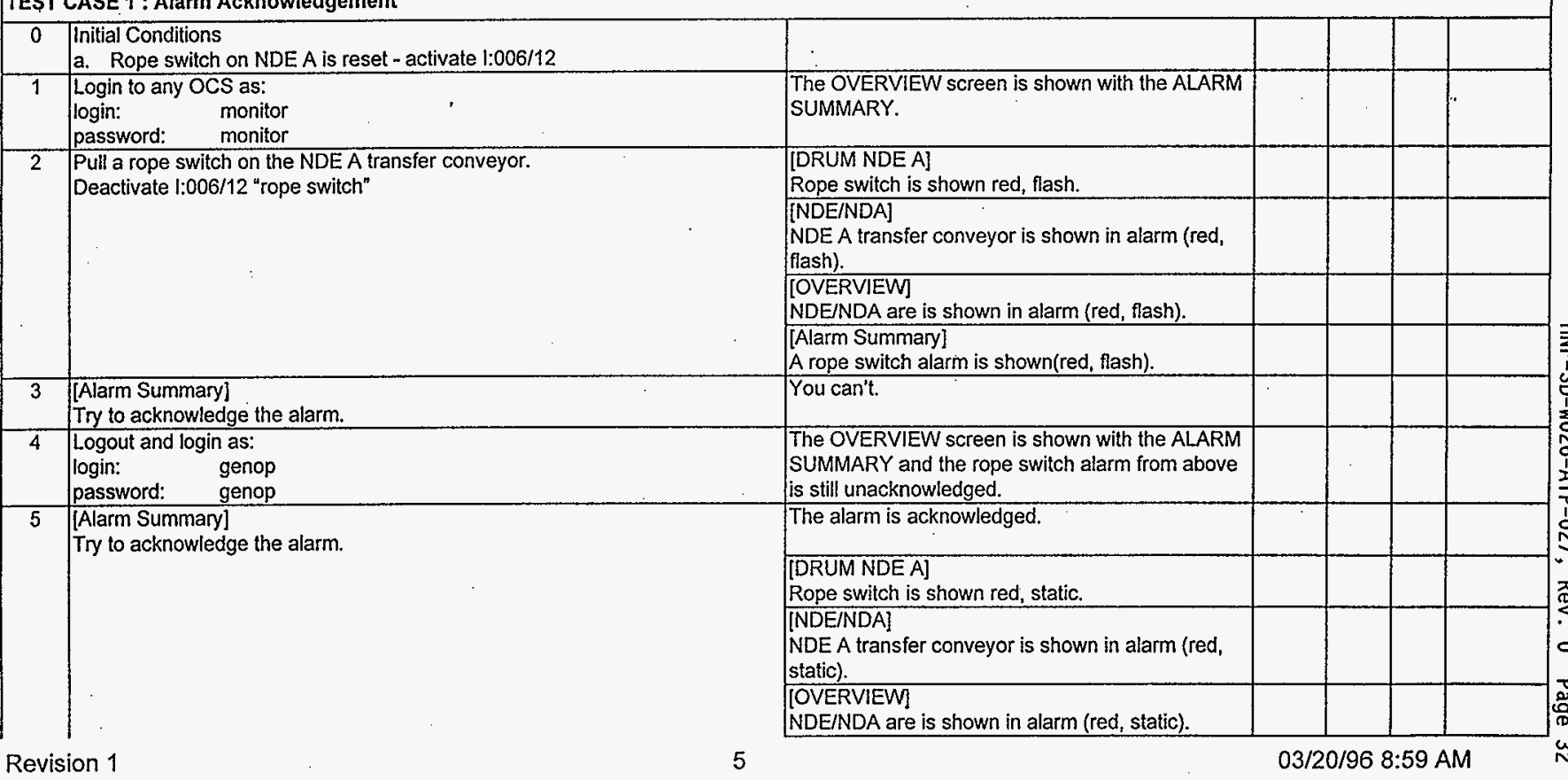




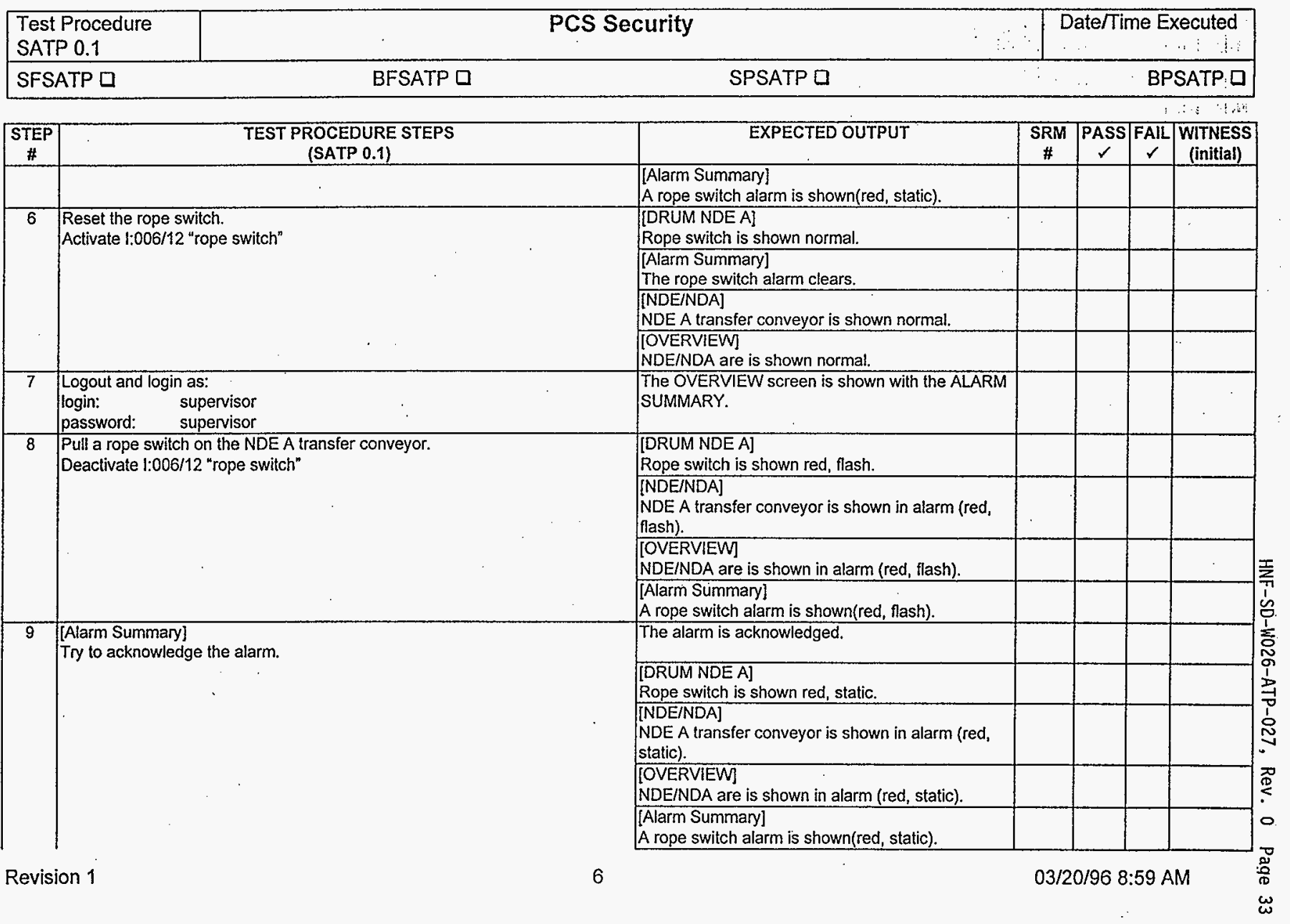




\begin{tabular}{|l|cc|c|}
\hline $\begin{array}{l}\text { Test Procedure } \\
\text { SATP } 0.1\end{array}$ & PCS Security & $\vdots$ & $\begin{array}{c}\text { Date/Time Executed } \\
\text { SFSATP } \square\end{array}$ \\
\hline
\end{tabular}

\begin{tabular}{|c|c|c|c|c|c|c|}
\hline \begin{tabular}{c|c|} 
STEP \\
$\#$
\end{tabular} & $\begin{array}{l}\text { TEST PROCEDURE STEPS } \\
\text { (SATP 0.1) }\end{array}$ & EXPECTED OUTPUT & $\begin{array}{c}\text { SRM } \\
\#\end{array}$ & \begin{tabular}{|c|c|c|c|} 
PASS \\
$r$
\end{tabular} & $\begin{array}{c}\text { FAlL } \\
\checkmark \\
\end{array}$ & $\begin{array}{c}\text { WITNESS } \\
\text { (initial) }\end{array}$ \\
\hline & $\begin{array}{ll}\text { login: } & \text { supervisor } \\
\text { password: } & \text { supervisor }\end{array}$ & & & & & \\
\hline 7 & $\begin{array}{l}\text { Switch to the HVAC - PROCESS EXHAUST screen. } \\
\text { Select the flow control valve } 618 \mathrm{~A} \text {. }\end{array}$ & $\begin{array}{l}\text { [SETPOINT CONTROL] } \\
\text { This window pops up for the selected flow control } \\
\text { valve. }\end{array}$ & & & & \\
\hline 8 & $\begin{array}{l}\text { [SETPOINT CONTROL] } \\
\text { Change the value in the "New Setpoint" field and press APPLY. } \\
\text { Wait } 30 \text { seconds. } \\
\text { Press the RESET. }\end{array}$ & $\begin{array}{l}\text { [SETPOINT CONTROL] } \\
\text { Both the "Current Setpoint" and the "New Setpoint" } \\
\text { fields have the new value. }\end{array}$ & & & & 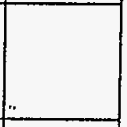 \\
\hline END & & & & & & \\
\hline \multicolumn{7}{|c|}{ TEST CASE $3:$ Alarm Enable/Disable } \\
\hline 0 & $\begin{array}{l}\text { Initial Conditions } \\
\text { a. If not already, login to any OCS as: } \\
\text { login: monitor } \\
\text { password: monitor }\end{array}$ & & & & & \\
\hline 1 & $\begin{array}{l}\text { Switch to the HEALTH PHYSICS MONITORING screen. } \\
\text { Select the alpha radiation monitor in Shipping/Receiving (RITA-511). }\end{array}$ & $\begin{array}{l}\text { [HEALTH PHYSICS - ALARM LIMIT CONTROL] } \\
\text { This window pops up with the ENABLED box } \\
\text { depressed (i.e, the alarm is ENABLED). }\end{array}$ & & & & \\
\hline 2 & $\begin{array}{l}\text { [HEALTH PHYSICS - ALARM LIMIT CONTROL! } \\
\text { Select the ENABLED box. }\end{array}$ & $\begin{array}{l}\text { [HEALTH PHYSICS - ALARM LIMIT CONTROL] } \\
\text { The ENABLED box is shown out. }\end{array}$ & & & & \\
\hline 3 & $\begin{array}{l}\text { [HEALTH PHYSICS - ALARM LIMIT CONTROL] } \\
\text { PresS APPLY. } \\
\text { PresS RESET. }\end{array}$ & $\begin{array}{l}\text { [HEALTH PHYSICS - ALARM LIMIT CONTROL] } \\
\text { The ENABLED box is shown depressed (i.e. the } \\
\text { alarm is still enabled). }\end{array}$ & & & & \\
\hline 4 & $\begin{array}{ll}\text { Logout and login as: } \\
\text { login: } & \text { genop } \\
\text { password: } & \text { genop } \\
\end{array}$ & & & & & \\
\hline 5 & $\begin{array}{l}\text { Switch to the HEALTH PHYSICS MONITORING screen. } \\
\text { Select the alpha radiation monitor in Shipping/Receiving (RITA-511). }\end{array}$ & $\begin{array}{l}\text { [HEALTH PHYSICS - ALARM LIMIT CONTROL] } \\
\text { This window pops up with the ENABLED box } \\
\text { depressed (i.e. the alarm is ENABLED). }\end{array}$ & & & & \\
\hline 6 & $\begin{array}{l}\text { [HEALTH PHYSICS - ALARM LIMIT CONTROL] } \\
\text { Select the ENABLED box. }\end{array}$ & $\begin{array}{l}\text { [HEALTH PHYSICS - ALARM LIMIT CONTROL] } \\
\text { The ENABLED box is shown out. }\end{array}$ & & & & \\
\hline 7 & [HEALTH PHYSICS - ALARM LIMIT CONTROL] & [HEALTH PHYSICS - ALARM LIMIT CONTROL] & & & & \\
\hline
\end{tabular}




\begin{tabular}{|c|c|c|}
\hline $\begin{array}{l}\text { Test Procedure } \\
\text { SATP } 0.2\end{array}$ & Alarm and Event Monitoring & Date/Time Executed \\
\hline SFSATP & SPSATP D & BPSATP \\
\hline
\end{tabular}

\section{Revision Status}

This test procedure is based on Specification Section 13461 and 13462 requirements

$\therefore$ for the alarm system and has incorporated all of the applicable engineering changes received by and requests for information issued by Systems Interface to date.

.....m.n.

Release/Revision Abstract:

Pre-release approval review.

\begin{tabular}{|c|l|l|}
\hline $\begin{array}{c}\text { Release/Revision } \\
\text { Number }\end{array}$ & Abstract & $\begin{array}{l}\text { Release } \\
\text { Date }\end{array}$ \\
\hline $0-0 . x$ & Pre-release approval reviews & $2 / 12 / 96$ \\
\hline 1 & Formal Submittal & $3 / 22 / 96$ \\
\hline & & \\
\hline & & - \\
\hline
\end{tabular}

